medRxiv preprint doi: https://doi.org/10.1101/2021.04.26.21256086; this version posted May 24, 2021. The copyright holder for this preprint

\title{
A Prospective Longitudinal Study of Health-Related Quality of Life and Psychological Wellbeing after an Implantable Cardioverter Defibrillator in Patients with Genetic Heart Diseases
}

Lieke M. van den Heuvel, MSc, a,b,c Tanya Sarina, MPH, ${ }^{a}$ Joanna Sweeting, PhD, a,c,d Laura Yeates, GradDipGenCouns, ${ }^{\text {a,c-e }}$ Kezia Bates, MGC, ${ }^{\text {a,d }}$ Catherine Spinks, MGC, ${ }^{\text {a }}$ Catherine O’Donnell, RN HDip, ${ }^{a}$ Samuel F. Sears, PhD, ${ }^{f}$ Kevin McGeechan, PhD, ${ }^{d}$

Christopher Semsarian, MBBS PhD MPH, , d,e Jodie Ingles, GradDipGenCouns PhD MPHa,c-e

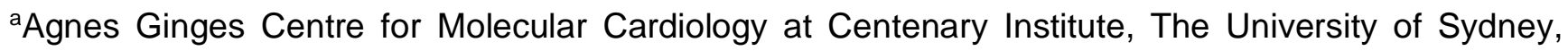
Australia;

bDepartment of Clinical Genetics, Amsterdam UMC, Location AMC, Amsterdam, the Netherlands;

${ }^{\circ}$ Cardio Genomics Program at Centenary Institute, The University of Sydney, Australia.

dFaculty of Medicine and Health, The University of Sydney, Australia;

eDepartment of Cardiology, Royal Prince Alfred Hospital, Sydney, Australia;

'Department of Psychology and Cardiovascular Sciences, East Carolina University, Greenville, North Carolina, USA;

Running title: Psychological follow-up after ICD in genetic heart disease patients

Word count: 4500 (including abstract and references)

Disclosures: J. Ingles receives research grant support from Myokardia, Inc. S.F. Sears, PhD: Honoraria/Consulting Fees: Medtronic, Abbott, ZOLL Medical; Research Grants: Medtronic, ZOLL Medical. All research funds are directed to East Carolina University.

\section{Address for correspondence:}

Associate Professor Jodie Ingles

Clinical Genomics Laboratory

Centre for Population Genomics, The Garvan Institute of Medical Research and Murdoch Children's Research Institute

384 Victoria Street, Darlinghurst NSW, 2010 Sydney Australia

E. jodie.ingles@populationgenomics.org.au Twitter. @jodieingles27

Keywords: Implantable cardioverter defibrillator, sudden cardiac death, health-related quality of life 
medRxiv preprint doi: https://doi.org/10.1101/2021.04.26.21256086; this version posted May 24, 2021. The copyright holder for this preprint (which was not certified by peer review) is the author/funder, who has granted medRxiv a license to display the preprint in perpetuity.

\section{ABSTRACT}

Background: Genetic heart diseases often affect young people, can be clinically heterogeneous and pose an increased risk of sudden cardiac death (SCD). The implantable cardioverter defibrillator (ICD) is a lifesaving therapy. Impacts on prospective and long-term psychological and health-related quality of life (HR-QoL) after ICD implant in patients with genetic heart diseases are unknown. We investigate the psychological functioning and HRQoL over time in patients with genetic heart diseases who receive an ICD, and identify risk factors for poor psychological functioning and HR-QoL.

Methods: A longitudinal, prospective study design was used. Patients attending a specialised clinic and diagnosed with a genetic heart disease, for which they received an ICD between May 2012 and January 2015, were eligible. Baseline surveys were completed prior to ICD implantation with five-year follow-up after ICD implant. We measured psychological functioning (Hospital Anxiety Depression Scale, Florida Shock Anxiety Scale), HR-QoL (Short-Form 36v2) and device acceptance (Florida Patient Acceptance Scale).

Results: There were 40 patients with an inherited cardiomyopathy or arrhythmia syndrome included (mean age $46.3 \pm 14.2$ years; $65.0 \%$ males). Mean psychological and HR-QoL measures were within normative ranges during follow-up. After 12 months, 33.3\% and $19.4 \%$ of participants showed clinically elevated levels of anxiety and depression, respectively. Longitudinal mixed effect analysis showed significant improvements from baseline to first follow-up for the overall cohort, with variability increasing after 36 months. Low education and female gender predicted worse mental HR-QoL and anxiety over time, while comorbidities predicted depression and worse physical HR-QoL.

Conclusion: While the majority of patients with a genetic heart disease adjust well to their ICD implant, a subset of patients' experience poor psychological and HR-QoL outcomes. 
medRxiv preprint doi: https://doi.org/10.1101/2021.04.26.21256086; this version posted May 24, 2021. The copyright holder for this preprint (which was not certified by peer review) is the author/funder, who has granted medRxiv a license to display the preprint in perpetuity.

\section{INTRODUCTION}

Genetic heart diseases include inherited cardiomyopathies and arrhythmia syndromes. They are characterized by clinical heterogeneity, with outcomes ranging from minimal symptoms to severe heart failure and sudden cardiac death (SCD) [1]. For those considered at increased risk of SCD, due to factors such as family history, unexplained syncope, prior cardiac arrest or sustained ventricular tachycardia, an implantable cardioverter defibrillator (ICD) is recommended [2]. While potentially life-saving, ICD implantation carries the risk of inappropriate shocks and complications in patients with genetic heart diseases [3].

ICD implantation can have a detrimental impact on psychological functioning and healthrelated quality of life (HR-QoL) in a subset of patients [4-6]. Several factors may contribute to patients being vulnerable to negative psychological outcomes and worse HR-QoL, such as female gender, type D personality (i.e., a combination of negative affectivity and social inhibition), increased anxiety and depression at baseline, ICD shocks, comorbidities and a young age at implant ( $<45$ years) [7-12]. Due to heterogeneity in study methodologies, existing literature shows mixed evidence, with multiple studies reporting similar or even improved HRQoL after ICD implantation compared to standard medical therapy [13-16] or pacemakers [17].

Research to understand psychological outcomes and HR-QoL has been conducted mostly in the setting of coronary artery disease $[4,6-8,10-13,16,17]$, where patients are generally older, i.e., mean age $>60$ years. Comparatively fewer studies have focused on patients with genetic heart diseases. While most patients show good adaptation [18-23], there is an important subgroup that report symptoms of anxiety, depression and posttraumatic stress symptoms $[18,19,22]$. Most studies have so far been cross-sectional, making it difficult to draw conclusions regarding causation. We performed a prospective, longitudinal cohort study with five-year follow-up, which aimed to investigate the psychological functioning and HR-QoL over 
medRxiv preprint doi: https://doi.org/10.1101/2021.04.26.21256086; this version posted May 24, 2021. The copyright holder for this preprint (which was not certified by peer review) is the author/funder, who has granted medRxiv a license to display the preprint in perpetuity. It is made available under a CC-BY-ND 4.0 International license.

time in patients diagnosed with genetic heart diseases who receive an ICD. Further, we investigated risk factors for poor psychological functioning and HR-QoL. 
medRxiv preprint doi: https://doi.org/10.1101/2021.04.26.21256086; this version posted May 24, 2021. The copyright holder for this preprint (which was not certified by peer review) is the author/funder, who has granted medRxiv a license to display the preprint in perpetuity.

\section{METHODS}

\section{Participants}

Patients attending a specialised multidisciplinary genetic heart disease clinic in Sydney, Australia who underwent implantation of an ICD between May 2012 and January 2015 were invited to participate. Individuals were eligible for the study if they were aged 18 years or older, had English-skills sufficient to complete the survey, and had received a diagnosis of an inherited arrhythmia syndrome or inherited cardiomyopathy. Patients considered likely to be recommended an ICD were approached prior to their initial clinic appointment and invited to complete a general survey focused on their psychological wellbeing and quality of life. Some patients were approached in hospital prior to surgical implantation of their ICD. Only patients who eventually underwent ICD insertion and completed at least one follow-up survey were considered study participants. The study was approved by the local institutional ethics committee and all patients provided written informed consent.

\section{Data collection}

Clinical and demographic data were obtained from the Australian Genetic Heart Disease Registry, and/or the medical record, which are continually updated and reviewed by cardiologists and other health professionals. Data collected included basic demographics, including gender, age, ethnicity, education level (low=below university, high=university or higher) and socioeconomic status (SES, based on the Index of Relative Socioeconomic Advantage and Disadvantage (IRSAD)). The IRSAD is used by the Australian Bureau of Statistics to summarize information about the economic and social conditions of people living within certain areas (24). Clinical information, such as clinical diagnosis, presence of comorbidities, and family history were collected. Details regarding ICD implantation and outcomes, including number of shocks at follow-up, were also collected. 
medRxiv preprint doi: https://doi.org/10.1101/2021.04.26.21256086; this version posted May 24, 2021. The copyright holder for this preprint (which was not certified by peer review) is the author/funder, who has granted medRxiv a license to display the preprint in perpetuity.

\section{Patient surveys}

Several validated scales were administered at baseline and several follow-up time points, 1-3 months, 6 months and every 12 months post-ICD implant. Participants were contacted by phone or email and invited to complete the follow-up survey. Scales included:

The Medical Outcomes Short Form 36 version 2 (SF-36v2): The Medical Outcomes Short Form 36 version 2 (SF-36v2) is a validated scale measuring HR-QoL $[25,26]$. The SF-36v2 is comprised of 36 items and provides a score (range 1-100) for eight sub-domains (physical functioning, role limitations due to physical health, general health, social functioning, bodily pain, vitality, role limitations due to emotional health and mental health) and two composite scores (physical component score; PCS and mental component score; MCS). Only PCS and MCS scores were included in this analysis. MCS and PCS scores were converted to Australian weighted T-scores. The weighted T-scores range from 0 (worst possible health) to 100 (best possible health) [27]. A score of 50 is the mean score for the general Australian population.

Hospital Anxiety and Depression Scale: The Hospital Anxiety and Depression Scale (HADS) is a validated measure of psychological wellbeing over the last seven days, used extensively in the hospital setting [28]. It is comprised of 14 items from which summary scores of anxiety and depression can be determined (range 0 to 21). A cut-off score of $\geq 8$ is used to describe clinically elevated levels of anxiety and depression that may warrant further investigation, as previously shown in an HCM population [29].

Florida Patient Acceptance Scale \& Florida Shock Anxiety Scale: The Florida Patient Acceptance Scale (FPAS) and the Florida Shock Anxiety Scale (FSAS) were included [30,31]. The FPAS comprises 18 items and is used to assess acceptance of the ICD. It provides measures of return to life, positive appraisal, device-related distress and body image concerns 
medRxiv preprint doi: https://doi.org/10.1101/2021.04.26.21256086; this version posted May 24, 2021. The copyright holder for this preprint (which was not certified by peer review) is the author/funder, who has granted medRxiv a license to display the preprint in perpetuity. It is made available under a CC-BY-ND 4.0 International license .

[30]. The FSAS includes 10 items and aims to determine the patient's anxiety related to the consequences and triggers of an ICD shock [31]. Both the FPAS and FSAS use a 5-point Likert scale and provide a summary score of overall acceptance and anxiety, respectively. A higher score on the FPAS indicates higher acceptance of the device, whereas a higher score on the FSAS indicates a higher level of anxiety regarding shocks.

\section{Statistical analysis}

Data were analysed using SAS Studio statistical software (Version 5.2) and R Studio (Version 1.2.1335). Data were visualised using the $R$ ggplot2 package. Sample characteristics and survey-responses are described as means (SD) or median (IQR), as appropriate. The longitudinal changes in HADS, SF-36v2, FSAS and FPAS were estimated using linear mixed models with a random intercept (Ime4 package, version 1.1-21), which assumes that missing data are missing at random [17]. Repeated measurements were nested within subjects. Time was included as a categorical variable in the analyses. Due to the extensive follow-up period of five years, many other factors might have influenced our psychological and HR-QoL outcomes. Therefore, baseline measures of age category (i.e., young $<40$ years old and older $\geq 40$ years old), gender, education level, and the presence of comorbidities and shocks were included as fixed effects in the mixed model analysis. The $p$-values are shown for these analyses, however due to known limitations of their use with the Imer4 package, confidence intervals have been primarily used in interpretation of results. 
medRxiv preprint doi: https://doi.org/10.1101/2021.04.26.21256086; this version posted May 24, 2021. The copyright holder for this preprint (which was not certified by peer review) is the author/funder, who has granted medRxiv a license to display the preprint in perpetuity.

\section{RESULTS}

\section{Population characteristics and response rates}

In total, 91 participants were approached prior to ICD implant, where there was a suspicion an ICD may eventually be recommended. Of these, 63 (69.2\%) completed a baseline survey, including $23(36.5 \%)$ who completed the baseline survey prior to discussion with the doctor about an ICD recommendation, 38 (60.3\%) after an ICD was recommended and 1 (1.6\%) which was uncertain. Overall, 42 (66.7\%) went on to have an ICD, with 40 going on to complete at least one follow-up survey (considered study participants), and 2 declining to complete further surveys. There were $4 / 63(6.3 \%)$ who declined an ICD and were deemed ineligible, and $17 / 63(27.0 \%)$ where an ICD was deemed not indicated.

Table 1 shows the demographic and clinical characteristics of the 40 participants at baseline. Mean age was $46.3 \pm 4.0$ years (range 19.8 to 66.1 years), 26 (65.0\%) were male and 33 were of European ethnicity (83\%). A third (14/40,35.0\%) had a university education and most participants had a high socioeconomic status $(23 / 40,57.5 \%)$. The most common genetic heart disease was $\mathrm{HCM}(30 / 40,75.0 \%)$ and $43.0 \%$ of patients (17/40) had comorbidities, including stroke, kidney disease, diabetes, cancer, asthma and arthritis. Only five patients (13.0\%) had shocks during follow-up (range: 1-3 shocks).

\section{Impact on psychological functioning}

Figure 1 shows the predicted values of the psychological and HR-QoL outcome measures. Mean HADS-anxiety and depression scores were below the cut-off score of 8 at baseline and each follow-up time point, although large standard deviations were observed (see Table 2). Almost half of participants (19/40, 47.5\%) indicated increased anxiety (HADS anxiety $\geq 8$ ) at baseline and $33.3 \%$ (12/36) beyond 12 months post-implant. Overall, 14 participants (35\%) scored $\geq 8$ at one point $>12$ months during follow-up. Of those patients who had clinically 
medRxiv preprint doi: https://doi.org/10.1101/2021.04.26.21256086; this version posted May 24 , 2021. The copyright holder for this preprint (which was not certified by peer review) is the author/funder, who has granted medRxiv a license to display the preprint in perpetuity. It is made available under a CC-BY-ND 4.0 International license.

elevated levels of anxiety at baseline, 14/19 (42.8\%) also showed clinically elevated levels during follow-up.

Anxiety symptoms initially increased but gradually improved over time, compared to baseline, with a significant improvement in HADS anxiety score after 4 years $(95 \% \mathrm{Cl}-14.05--2.87$, $p=0.017$ ). In addition, participants with university-level education (HADS anxiety score 2.55 points lower, 95\% Cl -4.98--0.11, $\mathrm{p}=0.070$ ) and male participants (HADS anxiety score 2.47 points lower, $95 \% \mathrm{Cl}-4.96-0.00, \mathrm{p}=0.084$ ) had less anxiety symptoms. Predictors including age, ethnicity and the presence of comorbidities or shocks, did not show an effect. Further, none of these predictors showed a significant interaction with time.

With respect to depression, 25.0\% (10/40) reported symptoms of depression (HADS depression $\geq 8)$ at baseline, and 19.4\% (7/36) at 1-year post-implant. Overall, 5 participants reported depression symptoms at one point $>1$ year during follow-up. At follow-up, HADSdepression scores showed an improvement over time compared to baseline. Participants with comorbidities were predicted to have worse depression symptoms (HADS depression score 2.17 points higher, $95 \% \mathrm{Cl} 0.04-4.27, \mathrm{p}=0.081$ ) than participants without comorbidities (see Table 3).

\section{Impact on HR-QoL}

The mean mental component score $(\mathrm{MCS}=39.4)$ was overall lower (worse) than the physical component score $(\mathrm{PCS}=49.2)$ and both gradually improved over time, although large standard deviations were observed (Table 2).

Mental component scores gradually improved over time (see Table 4), with significant improvement after two years $(95 \% \mathrm{Cl} 3.27$ - 26.97, $\mathrm{p}=0.032)$. Predictors including age, 
medRxiv preprint doi: https://doi.org/10.1101/2021.04.26.21256086; this version posted May 24, 2021. The copyright holder for this preprint (which was not certified by peer review) is the author/funder, who has granted medRxiv a license to display the preprint in perpetuity. It is made available under a CC-BY-ND 4.0 International license.

education, ethnicity and the presence of comorbidities or shocks, did not significantly contribute to the model. However, male patients scored 8.79 points better than female patients on mental HR-QoL $(95 \% \mathrm{Cl} 0.34-17.18, \mathrm{p}=0.072)$. Also, none of the predictors included in the model showed a significant interaction with time.

Over time a gradual improvement in physical component scores was observed, after an initial significant decrease at 3 months follow-up $(95 \% \mathrm{Cl}-14.46--2.85, \mathrm{p}=0.013)$. The presence of comorbidities showed a significant effect on predicted physical component score values, with participants with comorbidities scoring 8.99 points lower than participants without comorbidities $(95 \% \mathrm{Cl}-14.14--2.61, \mathrm{p}=0.014)$. We observed no significant interaction effects with time.

\section{Shock anxiety}

Mean scores for shock anxiety gradually increased over time, though the sample size decreased substantially with time (Table 2). A significant improvement in shock anxiety was observed at 4 years $(95 \% \mathrm{Cl}-19.76--3.87, p=0.023)$, compared to the first measure $(1-3$ months; Table 3). The predictors included in the model did not show a significant effect nor significant interactions with time.

\section{Device acceptance}

Mean scores on the FPAS scale show a gradual improvement in patient acceptance of their ICD after the first 6 months, with large standard deviations (Table 2). FPAS scores improved over time, with a significant improvement after 6 months $(95 \% \mathrm{Cl} 4.81-27.89, \mathrm{p}=0.028)$, one year $(95 \% \mathrm{Cl} 8.13-35.34, \mathrm{p}=0.013)$ and after 4 years $(95 \% \mathrm{Cl} 20.01-67.64, \mathrm{p}=0.005)$, compared to the first three months after ICD implantation. Predictors did not show a significant contribution to the model, and none of the predictors showed significant interactions with time. 
medRxiv preprint doi: https://doi.org/10.1101/2021.04.26.21256086; this version posted May 24, 2021. The copyright holder for this preprint (which was not certified by peer review) is the author/funder, who has granted medRxiv a license to display the preprint in perpetuity.

\section{DISCUSSION}

Despite being life-saving, implantation of an ICD can have important psychological functioning and health-related quality of life impacts. With most evidence based on older cardiovascular disease populations, in contrast patients diagnosed with a genetic heart disease are often younger in age at diagnosis, have minimal or no symptoms, and must deal with the heritable nature of the disease $[18,19,32]$. We show that while mean values of psychological and HRQoL measures were within the normal range over time, the large variability in confidence intervals and standard deviations highlighted the wide range of responses. Furthermore, a sizeable subgroup of patients showed clinically elevated levels of anxiety and depression during early follow-up. Lower education level and female gender were identified as a predictor for worse mental HR-QoL and anxiety, while the presence of comorbidities predicted symptoms of depression and worse physical HR-QoL.

Our findings support prior cross-sectional studies in the genetic heart disease population, which show that while most patients adjust well to their ICD, an important subgroup do have ongoing psychological difficulties [18,19,21-23]. Due to our longitudinal study design, we show for the first time that overall psychological wellbeing and mental HR-QoL improve over time. However, it is important to note the increasing variability for all measures observed after three years follow-up. Longitudinal studies investigating the effect of ICD implant in a heterogeneous group of patients report a gradual improvement in outcomes over time [33-35], or indicate an initial improvement [14]. However, follow-up periods described in these studies differ substantially, and as we found, it is challenging to control for the numerous other life events that occur with such long-term follow-up periods, which impact on emotional wellbeing and HRQoL. 
medRxiv preprint doi: https://doi.org/10.1101/2021.04.26.21256086; this version posted May 24, 2021. The copyright holder for this preprint (which was not certified by peer review) is the author/funder, who has granted medRxiv a license to display the preprint in perpetuity. It is made available under a CC-BY-ND 4.0 International license .

Higher general anxiety scores in ICD patients over time were observed in female patients and patients with lower education levels. Female gender has previously been identified as a predictor for poor psychological functioning and HR-QoL [7,12]. Previous work examining ICD implantation in individuals with coronary artery disease found no association between education level and worse psychological functioning [37,38]. Wong et al. [39] found an association between low education level and worse depression scores, but reported no association with anxiety. It is important to note however, that many studies have not included education level in their analyses [18-22]. While previous research has identified a younger age as a risk factor for poor psychological outcomes and HR-QoL in patients with genetic heart disease $[19,21,22]$, this was not observed in our longitudinal data. Type D personality and being optimistic have been identified as strong predictors for psychological outcomes in studies in ICD patients with coronary artery disease and myocardial infarction $[11,38]$. Furthermore, the perception of social support has been considered a predictor for psychological adjustment to an ICD and may therefore be an interesting predictor as well [37]. These factors have not been included in research on long-term psychological outcomes after ICD implantation in patients with genetic heart disease so far $[18,19,22]$.

Our study design has several limitations, including the relatively small sample size and response rate drop off over time. Collecting baseline surveys prior to ICD implantation presented a major challenge in recruitment for this study and led to our small sample size. This may have limited our power to identify relevant predictors of poor psychological functioning of HR-QoL. Furthermore, we cannot be sure if drop-out over time influenced our outcomes. In addition, very few patients in our cohort received shocks, meaning prospective evaluation of the impact of shocks could not be reliably assessed. Previous research has identified the presence and number of shocks as an important predictor of poor psychological outcomes, and therefore our data may underestimate the effect of ICD implantation on psychological 
medRxiv preprint doi: https://doi.org/10.1101/2021.04.26.21256086; this version posted May 24, 2021. The copyright holder for this preprint (which was not certified by peer review) is the author/funder, who has granted medRxiv a license to display the preprint in perpetuity. It is made available under a CC-BY-ND 4.0 International license.

functioning and HR-QoL. Of note, a large Swedish study of ICD patients $(N>3000)$ suggested that concern about a potential shock, rather than the shock itself, predicted poor outcomes [12].

Overall, our findings indicate that although a majority of patients adjust well to their ICD, those with poor baseline psychological functioning and HR-QoL pre-implantation, females, lower education level and presence of comorbidities, are at increased risk of experiencing anxiety, depression and/or worse HR-QoL post-implant. Ideally, these patients should be identified in clinic and monitored carefully during follow-up. Psychosocial support and interventions might be effective in diminishing distress and reducing anxiety and depressive symptoms in these patients. While psychological interventions, including psycho-education and cognitive behavioural therapy, have shown to be effective in ICD patients with other, non-genetic heart diseases [40], no intervention research has been performed in those with genetic heart diseases specifically. Due to the unique circumstances that these patients face, including the young age at diagnosis, often being relatively asymptomatic despite having high risk of SCD, and the heritable nature of disease, tailored interventions are likely to be more effective. Since our findings suggest that there is increasing variability after three years, support programs and interventions should ideally incorporate a longer-term follow-up for patients who are at risk of poor psychological functioning.

\section{CONCLUSIONS}

We report the first longitudinal self-report survey study to evaluate psychological functioning and health-related quality of life after ICD implantation in patients with genetic heart diseases. We show normative psychological outcomes over time, although the large variability observed highlights the diverse responses. An important subgroup of patients showed clinically elevated levels of anxiety and depression during follow-up, with low education level, female gender and 
medRxiv preprint doi: https://doi.org/10.1101/2021.04.26.21256086; this version posted May 24, 2021. The copyright holder for this preprint (which was not certified by peer review) is the author/funder, who has granted medRxiv a license to display the preprint in perpetuity. th is made available under a CC-BY-ND 4.0 International license.

the presence of comorbidities being predictors of poor psychological functioning and HR-QoL. Patients vulnerable to developing poor psychological outcomes should ideally be identified in clinic and carefully monitored. Tailored psychosocial support and interventions might be effective to diminish distress and relieve anxiety and depressive symptoms in this unique patient group. 
medRxiv preprint doi: https://doi.org/10.1101/2021.04.26.21256086; this version posted May 24, 2021. The copyright holder for this preprint (which was not certified by peer review) is the author/funder, who has granted medRxiv a license to display the preprint in perpetuity.

\section{FUNDING}

LM van den Heuvel is a PhD student funded by a grant of the Netherlands Cardiovascular Research Initiative, an initiative with support of the Dutch Heart Foundation (2015-12 eDETECT) and the eDETECT Young Talent Fund CVON grant (CVON2015-2). C Semsarian is the recipient of a National Health and Medical Research Council (NHMRC) Practitioner Fellowship (\#1059156). L. Yeates is a recipient of a co-funded National Heart Foundation of Australia and National Health and Medical Research Council (NHMRC) PhD scholarship (\#102568 and \#191351). J Ingles is the recipient of a NHMRC Career Development Fellowship (\#1162929). This study is funded in part by an NHMRC Project Grant (\#1059515) and National Heart Foundation Future Leader Fellowship (\#100833).

\section{DISCLOSURES}

J. Ingles receives research grant support from Myokardia, Inc. S.F. Sears, PhD: Honoraria/Consulting Fees: Medtronic, Abbott, ZOLL Medical; Research Grants: Medtronic, ZOLL Medical. All research funds are directed to East Carolina University. 
medRxiv preprint doi: https://doi.org/10.1101/2021.04.26.21256086; this version posted May 24, 2021. The copyright holder for this preprint (which was not certified by peer review) is the author/funder, who has granted medRxiv a license to display the preprint in perpetuity.

\section{REFERENCES}

1. Wilde AA, Behr ER. Genetic testing for inherited cardiac disease. Nat Rev Cardiol 2013;10:571-83.

2. Maron BJ, Spirito P, Shen WK et al. Implantable cardioverter-defibrillators and prevention of sudden cardiac death in hypertrophic cardiomyopathy. JAMA 2007;298:405-12.

3. Olde Nordkamp LR, Postema PG, Knops RE et al. Implantable cardioverter-defibrillator harm in young patients with inherited arrhythmia syndromes: A systematic review and metaanalysis of inappropriate shocks and complications. Heart Rhythm 2016;13:443-54.

4. Magyar-Russell G, Thombs BD, Cai JX et al. The prevalence of anxiety and depression in adults with implantable cardioverter defibrillators: a systematic review. J Psychosom Res 2011;71:223-31.

5. Maron BJ, Casey SA, Olivotto I et al. Clinical Course and Quality of Life in High-Risk Patients With Hypertrophic Cardiomyopathy and Implantable Cardioverter-Defibrillators. Circ Arrhythm Electrophysiol 2018;11:e005820.

6. Tomzik J, Koltermann KC, Zabel M, Willich SN, Reinhold T. Quality of Life in Patients with an Implantable Cardioverter Defibrillator: A Systematic Review. Front Cardiovasc Med 2015;2:34.

7. Gopinathannair R, Lerew DR, Cross NJ, Sears SF, Brown S, Olshansky B. Longitudinal changes in quality of life following ICD implant and the impact of age, gender, and ICD shocks: observations from the INTRINSIC RV trial. J Interv Card Electrophysiol 2017;48:291-298.

8. Habibovic M, Denollet J, Pedersen SS, on behalf of the Wi. Posttraumatic stress and anxiety in patients with an implantable cardioverter defibrillator: Trajectories and vulnerability factors. Pacing Clin Electrophysiol 2017;40:817-823.

9. Israelsson J, Thylen I, Stromberg A, Bremer A, Arestedt K. Factors associated with healthrelated quality of life among cardiac arrest survivors treated with an implantable cardioverterdefibrillator. Resuscitation2018;132:78-84. 
medRxiv preprint doi: https://doi.org/10.1101/2021.04.26.21256086; this version posted May 24, 2021. The copyright holder for this preprint (which was not certified by peer review) is the author/funder, who has granted medRxiv a license to display the preprint in perpetuity. It is made available under a CC-BY-ND 4.0 International license.

10. Koopman HM, Vrijmoet-Wiersma CM, Langius JN et al. Psychological functioning and disease-related quality of life in pediatric patients with an implantable cardioverter defibrillator. PediatrCardiol 2012;33:569-75.

11. Miller JL, Thylen I, Elayi SC et al. Multi-morbidity burden, psychological distress, and quality of life in implantable cardioverter defibrillator recipients: Results from a nationwide study. J Psychosom Res 2019;120:39-45.

12. Thylen I, Dekker RL, Jaarsma T, Stromberg A, Moser DK. Characteristics associated with anxiety, depressive symptoms, and quality-of-life in a large cohort of implantable cardioverter defibrillator recipients. J PsychosomRes2014;77:122-7.

13. Haugaa KH, Potpara TS, Boveda S et al. Patients' knowledge and attitudes regarding living with implantable electronic devices: results of a multicentre, multinational patient survey conducted by the European Heart Rhythm Association. Europace 2018;20:386-391.

14. Mark DB, Anstrom KJ, Sun JL et al. Quality of life with defibrillator therapy or amiodarone in heart failure. N Engl J Med2008;359:999-1008.

15. Noyes K, Corona E, Zwanziger $\mathrm{J}$ et al. Health-related quality of life consequences of implantable cardioverter defibrillators: results from MADIT II. Med Care 2007;45:377-85.

16. Passman R, Subacius $\mathrm{H}$, Ruo B et al. Implantable cardioverter defibrillators and quality of life: results from the defibrillators in nonischemic cardiomyopathy treatment evaluation study. Arch Intern Med 2007;167:2226-32.

17. Leosdottir M, Sigurdsson E, Reimarsdottir G et al. Health-related quality of life of patients with implantable cardioverter defibrillators compared with that of pacemaker recipients. Europace 2006;8:168-74.

18. Ingles J, Sarina T, Kasparian N, Semsarian C. Psychological wellbeing and posttraumatic stress associated with implantable cardioverter defibrillator therapy in young adults with genetic heart disease. Int J Cardiol 2013;168:3779-84. 
medRxiv preprint doi: https://doi.org/10.1101/2021.04.26.21256086; this version posted May 24, 2021. The copyright holder for this preprint (which was not certified by peer review) is the author/funder, who has granted medRxiv a license to display the preprint in perpetuity. It is made available under a CC-BY-ND 4.0 International license.

19. James CA, Tichnell C, Murray B, Daly A, Sears SF, Calkins H. General and diseasespecific psychosocial adjustment in patients with arrhythmogenic right ventricular dysplasia/cardiomyopathy with implantable cardioverter defibrillators: a large cohort study. Circ Cardiovasc Genet 2012;5:18-24.

20. Probst V, Plassard-Kerdoncuf D, Mansourati $\mathrm{J}$ et al. The psychological impact of implantable cardioverter defibrillator implantation on Brugada syndrome patients. Europace $2011 ; 13: 1034-9$.

21. Rhodes AC, Murray B, Tichnell C, James CA, Calkins H, Sears SF. Quality of life metrics in arrhythmogenic right ventricular cardiomyopathy patients: The impact of age, shock and sex. Int J Cardiol 2017;248:216-220.

22. Richardson E, Spinks C, Davis A et al. Psychosocial Implications of Living with Catecholaminergic Polymorphic Ventricular Tachycardia in Adulthood. J Genet Couns 2018;27:549-557.

23. Sweeting J, Ball K, McGaughran J, Atherton J, Semsarian C, Ingles J. Impact of the implantable cardioverter defibrillator on confidence to undertake physical activity in inherited heart disease: A cross-sectional study. Eur J Cardiovasc Nurs 2017;16:742-752.

24. Wise PM, R. Socio-economic indexes for areas: Getting a handle on individual diversity within areas. Australian Bureau of Statistics 2011.

25. Ware JE, Kosinski M. Interpreting SF-36 summary health measures: a response. Qual Life Res 2001;10:405-13; discussion 415-20.

26. Ware JE, Jr., Sherbourne CD. The MOS 36-item short-form health survey (SF-36). I. Conceptual framework and item selection. Med Care 1992;30:473-83.

27. Hawthorne G, Osborne RH, Taylor A, Sansoni J. The SF36 Version 2: critical analyses of population weights, scoring algorithms and population norms. Qual Life Res 2007;16:661-73. 28. Zigmond AS, Snaith RP. The hospital anxiety and depression scale. Acta PsychiatrScand 1983;67:361-70. 
medRxiv preprint doi: https://doi.org/10.1101/2021.04.26.21256086; this version posted May 24, 2021. The copyright holder for this preprint (which was not certified by peer review) is the author/funder, who has granted medRxiv a license to display the preprint in perpetuity. It is made available under a CC-BY-ND 4.0 International license.

29. Poole NA, Morgan JF. Validity and reliability of the Hospital Anxiety and Depression Scale in a hypertrophic cardiomyopathy clinic: the HADS in a cardiomyopathy population. Gen Hosp Psychiatry 2006;28:55-8.

30. Burns JL, Serber ER, Keim S, Sears SF. Measuring patient acceptance of implantable cardiac device therapy: initial psychometric investigation of the Florida Patient Acceptance Survey. J Cardiovasc Electrophysiol 2005;16:384-90.

31. Kuhl EA, Dixit NK, Walker RL, Conti JB, Sears SF. Measurement of patient fears about implantable cardioverter defibrillator shock: an initial evaluation of the Florida Shock Anxiety Scale. Pacing Clin Electrophysiol 2006;29:614-8.

32. Caleshu C, Kasparian NA, Edwards KS et al. Interdisciplinary psychosocial care for families with inherited cardiovascular diseases. Trends Cardiovasc Med 2016;26:647-53.

33. Flemme I, Edvardsson N, Hinic H, Jinhage BM, Dalman M, Fridlund B. Long-term quality of life and uncertainty in patients living with an implantable cardioverter defibrillator. Heart Lung 2005;34:386-92.

34. Kapa S, Rotondi-Trevisan D, Mariano Z et al. Psychopathology in patients with ICDs over time: results of a prospective study. Pacing ClinElectrophysiol 2010;33:198-208.

35. Thomas SA, Friedmann E, Gottlieb SS et al. Changes in psychosocial distress in outpatients with heart failure with implantable cardioverter defibrillators. Heart Lung 2009;38:109-20.

36. Pedersen SS, Hoogwegt MT, Jordaens L, Theuns DA. Pre-implantation psychological functioning preserved in majority of implantable cardioverter defibrillator patients 12 months post implantation. Int J Cardiol 2013;166:215-20.

37. Rottmann N, Skov O, Andersen CM, Theuns D, Pedersen SS. Psychological distress in patients with an implantable cardioverter defibrillator and their partners. J Psychosom Res 2018;113:16-21. 
medRxiv preprint doi: https://doi.org/10.1101/2021.04.26.21256086; this version posted May 24, 2021. The copyright holder for this preprint (which was not certified by peer review) is the author/funder, who has granted medRxiv a license to display the preprint in perpetuity. It is made available under a CC-BY-ND 4.0 international license.

38. Versteeg H, Timmermans I, Meine M, Zitron E, Mabo P, Denollet J. Prevalence and risk markers of early psychological distress after ICD implantation in the European REMOTE-CIED study cohort. Int J Cardiol 2017;240:208-213.

39. Wong MF. Factors associated with anxiety and depression among patients with implantable cardioverter defibrillator. J ClinNurs 2017;26:1328-1337.

40. Dunbar SB, Dougherty CM, Sears SF et al. Educational and psychological interventions to improve outcomes for recipients of implantable cardioverter defibrillators and their families: a scientific statement from the American Heart Association. Circulation 2012;126:2146-72. 
medRxiv preprint doi: https://doi.org/10.1101/2021.04.26.21256086; this version posted May 24, 2021. The copyright holder for this preprint

(which was not certified by peer review) is the author/funder, who has granted medRxiv a license to display the preprint in perpetuity.

it is made available under a CC-BY-ND 4.0 International license.

TABLE 1: Sociodemographic and clinical characteristics at baseline

\section{Characteristics}

$\mathbf{N}(\%)$

Total (N)

Male gender

$26(65.0)$

Age range (mean, SD)

$19.8-66.1(46.3,14.2)$

European ethnicity

Education level ${ }^{*}$

Low

High

$14(35.0)$

Socioeconomic status at baseline ${ }^{\star \star}$

Low

Moderately low

Moderately high

High

\section{Disease type}

$\mathrm{HCM}$

DCM

ACM

$\mathrm{BrS}$

LQTS

\section{Comorbidities present}

\section{Patients with shocks during follow-up}

Abbreviations: HCM, Hypertrophic Cardiomyopathy; DCM, Dilated Cardiomyopathy; ACM, Arrhythmogenic Cardiomyopathy; BrS, Brugada Syndrome; LQTS, Long QT Syndrome.

*Education level was defined as low (below university) and high (university or higher)

${ }^{* *}$ Socioeconomic status was defined by the Australian IRSAD index (24). Data are

presented in categories: low = percentiles 0-24; moderately low = 25-49; moderately high = 50-74; high = 75-100) 
TABLE 2: Psychological and health-related quality of life outcome measures per timepoint

\begin{tabular}{|c|c|c|c|c|c|c|c|c|}
\hline & Baseline & 3 months & 6 months & 1 year & 2 years & 3 years & 4 years & 5 years \\
\hline & $N=40$ & $N=36$ & $N=32$ & $N=27$ & $N=21$ & $N=12$ & $N=13$ & $N=9$ \\
\hline HADS Anxiety & $6.9(4.0)^{*}$ & $6.4(4.1)$ & $5.5(3.7)$ & $5.4(3.8)$ & $5.6(3.3)$ & $5.8(4.9)$ & $5.0(3.3)$ & $5.1(3.8)$ \\
\hline HADS Depression & $4.8(3.8)$ & $4.2(3.8)$ & $3.6(3.3)$ & $3.5(2.6)$ & $3.2(3.0)$ & $4.5(4.0)$ & $2.3(2.4)$ & $4.1(4.4)$ \\
\hline SF-36 MCS & $39.4(13.0)$ & $40.7(15.3)$ & $46.4(10.1)$ & $44.9(11.1)$ & $45.3(11.1)$ & $44.3(15.8)$ & $48.6(6.3)$ & $52.7(3.7)$ \\
\hline SF-36 PCS & $49.2(9.6)$ & $43.1(8.2)$ & $50.5(7.6)$ & $48.9(9.0)$ & $48.5(9.3)$ & $49.9(11.6)$ & $56.1(5.1)$ & $51.6(7.0)$ \\
\hline FSAS & $-* *$ & $19.1(8.0)$ & $17.1(7.3)$ & $16.9(6.8)$ & $17.1(7.2)$ & $15.6(7.9)$ & $14.0(5.7)$ & $17.2(8.7)$ \\
\hline FPAS & $-* *$ & $70.9(18.2)$ & $76.8(17.2)$ & $81.7(11.8)$ & $75.2(15.7)$ & $80.1(15.1)$ & $79.1(17.9)$ & $74.8(17.7)$ \\
\hline
\end{tabular}

HADS Hospital Anxiety and Depression Scale, cut-off score = 8; MCS Mental Component Score, mean z-score = 50; PCS Physical Component Score, mean z-Score = 50, FSAS Florida Shock Anxiety Scale, FPAS Florida Patient Acceptance Scale

${ }^{*}$ Results are presented as mean (SD)

${ }^{\star *}$ The FSAS and FPAS measures were not included in the baseline measure, since baseline was prior to ICD implant 
TABLE 3: Estimated fixed effects of predictors for anxiety and depression

\begin{tabular}{|c|c|c|c|c|c|c|c|}
\hline \multirow[b]{2}{*}{ Measure } & \multirow[b]{2}{*}{ Variable } & \multicolumn{6}{|c|}{$95 \% \mathrm{Cl}$} \\
\hline & & Category & $\begin{array}{l}\text { Mean } \\
\text { change }\end{array}$ & Lower & Upper & $\begin{array}{l}P \text { for } \\
\text { main } \\
\text { effect }^{\text {a }}\end{array}$ & $\begin{array}{l}P \text { for } \\
\text { interaction } \\
\text { effect with } \\
\text { time }\end{array}$ \\
\hline \multirow{14}{*}{$\begin{array}{l}\text { HADS } \\
\text { anxiety }\end{array}$} & \multirow[t]{8}{*}{ Time } & Baseline & \multicolumn{4}{|l|}{ Reference } & \multirow[t]{8}{*}{$N A$} \\
\hline & & 3 months & 0.63 & -1.91 & 3.18 & 0.685 & \\
\hline & & 6 months & -1.42 & -4.15 & 1.26 & 0.395 & \\
\hline & & 1 year & -1.83 & -4.99 & 1.30 & 0.345 & \\
\hline & & 2 years & -1.20 & -5.45 & 3.12 & 0.650 & \\
\hline & & 3 years & 1.65 & -3.46 & 6.91 & 0.604 & \\
\hline & & 4 years & -8.26 & -14.05 & -2.87 & 0.017 & \\
\hline & & 5 years & -0.00 & -5.47 & -5.64 & 0.999 & \\
\hline & Age & $\geq \mathbf{4 0}$ & -0.07 & -2.46 & -2.41 & 0.962 & 0.077 \\
\hline & Gender & Male & -2.47 & -4.96 & 0.00 & 0.084 & 0.917 \\
\hline & Education & University & -2.55 & -4.98 & -0.11 & 0.070 & 0.387 \\
\hline & Ethnicity & White & 0.57 & -2.66 & 3.77 & 0.756 & 0.772 \\
\hline & Comorbidities & Present & 1.21 & -1.37 & 3.77 & 0.409 & 0.409 \\
\hline & Shocks & Yes & -0.32 & -3.82 & 3.19 & 0.873 & 0.324 \\
\hline \multirow{14}{*}{$\begin{array}{l}\text { HADS } \\
\text { depression }\end{array}$} & \multirow[t]{8}{*}{ Time } & Baseline & \multicolumn{4}{|l|}{ Reference } & \multirow[t]{8}{*}{$N A$} \\
\hline & & 3 months & 0.94 & -1.87 & 3.75 & 0.587 & \\
\hline & & 6 months & -0.11 & -3.08 & 2.89 & 0.952 & \\
\hline & & 1 year & -1.56 & -5.00 & 1.91 & 0.461 & \\
\hline & & 2 years & -1.02 & -5.63 & 3.77 & 0.724 & \\
\hline & & 3 years & 2.25 & -3.28 & 8.06 & 0.516 & \\
\hline & & 4 years & -2.45 & -8.67 & 3.53 & 0.511 & \\
\hline & & 5 years & -3.49 & -9.42 & 2.84 & 0.350 & \\
\hline & Age & $\geq 40$ & -0.96 & -3.00 & 1.18 & 0.430 & 0.408 \\
\hline & Gender & Male & -1.40 & -3.45 & 0.63 & 0.241 & 0.399 \\
\hline & Education & University & -1.96 & -3.96 & 0.04 & 0.095 & 0.916 \\
\hline & Ethnicity & White & 2.64 & -0.05 & 5.27 & 0.091 & 0.808 \\
\hline & \multirow{2}{*}{$\begin{array}{l}\text { Comorbidities } \\
\text { Shocks }\end{array}$} & Present & 2.17 & 0.04 & 4.27 & 0.081 & \multirow{2}{*}{$\begin{array}{l}0.755 \\
0.503\end{array}$} \\
\hline & & Yes & 1.81 & -1.07 & 4.69 & 0.281 & \\
\hline \multirow{14}{*}{$\begin{array}{l}\text { SF-36 } \\
\text { Mental } \\
\text { Component } \\
\text { Score } \\
\text { (MCS) }\end{array}$} & \multirow[t]{8}{*}{ Time } & Baseline & Reference & & & & \multirow[t]{8}{*}{$N A$} \\
\hline & & 3 months & 1.29 & -7.06 & 9.53 & 0.793 & \\
\hline & & 6 months & 8.81 & 0.20 & 17.30 & 0.083 & \\
\hline & & 1 year & 7.03 & -3.17 & 17.19 & 0.243 & \\
\hline & & 2 years & 15.13 & 3.27 & 26.97 & 0.032 & \\
\hline & & 3 years & -6.49 & -21.62 & 8.33 & 0.461 & \\
\hline & & 4 years & 12.48 & -2.24 & 27.18 & 0.153 & \\
\hline & & 5 years & 7.97 & -14.44 & 30.00 & 0.543 & \\
\hline & Age & $\geq 40$ & 0.08 & -8.59 & 8.42 & 0.986 & 0.455 \\
\hline & Gender & Male & 8.79 & 0.34 & 17.18 & 0.072 & 0.222 \\
\hline & Education & University & 2.81 & -5.29 & 10.85 & 0.544 & 0.227 \\
\hline & Ethnicity & White & 3.38 & -5.21 & 12.14 & 0.489 & $N A^{\mathrm{c}}$ \\
\hline & Comorbidities & Present & 2.19 & -6.44 & 10.83 & 0.658 & 0.532 \\
\hline & Shocks & Yes & -7.80 & -17.12 & 1.57 & 0.142 & $N A^{c}$ \\
\hline
\end{tabular}




\begin{tabular}{|c|c|c|c|c|c|c|c|}
\hline$S F-36$ & Time & Baseline & Reference & & & & $N A$ \\
\hline Physical & & 3 months & -8.65 & -14.46 & -2.85 & 0.013 & \\
\hline Component & & 6 months & 2.72 & -3.25 & 8.71 & 0.443 & \\
\hline Score & & 1 year & -0.55 & -7.64 & 6.63 & 0.897 & \\
\hline \multirow[t]{10}{*}{ (PCS) } & & 2 years & -1.61 & -9.87 & 6.75 & 0.744 & \\
\hline & & 3 years & 5.58 & -4.85 & 16.06 & 0.368 & \\
\hline & & 4 years & -4.19 & -14.53 & 6.08 & 0.492 & \\
\hline & & 5 years & 6.08 & -9.48 & 21.55 & 0.508 & \\
\hline & Age & $\geq 40$ & -1.65 & -8.78 & 4.22 & 0.637 & 0.787 \\
\hline & Gender & Male & -0.22 & -6.18 & 6.07 & 0.951 & 0.783 \\
\hline & Education & University & 3.65 & -2.19 & 9.49 & 0.275 & 0.118 \\
\hline & Ethnicity & White & 2.82 & -3.25 & 9.72 & 0.428 & $N A^{c}$ \\
\hline & Comorbidities & Present & -8.99 & -15.14 & -2.61 & 0.014 & 0.573 \\
\hline & Shocks & Yes & 5.43 & -1.45 & 12.36 & 0.162 & $N A^{c}$ \\
\hline \multirow{14}{*}{$\begin{array}{l}\text { Florida } \\
\text { Shock } \\
\text { Anxiety } \\
\text { Scale } \\
\text { (FSAS) }\end{array}$} & \multirow[t]{8}{*}{ Time } & 3 months & \multicolumn{4}{|l|}{ Reference } & \multirow[t]{8}{*}{$N A$} \\
\hline & & 6 months & 0.60 & -3.21 & 4.49 & \multirow{3}{*}{$\begin{array}{l}0.809 \\
0.483\end{array}$} & \\
\hline & & 1 year & -2.04 & -6.57 & 2.52 & & \\
\hline & & & & & & & \\
\hline & & 2 years & 0.45 & -5.65 & 6.66 & 0.909 & \\
\hline & & 3 years & 2.59 & -4.65 & 10.13 & 0.582 & \\
\hline & & 4 years & -11.77 & -19.76 & -3.87 & 0.023 & \\
\hline & & 5 years & 8.15 & 0.43 & 16.12 & \multirow{2}{*}{$\begin{array}{l}0.107 \\
0.109\end{array}$} & \\
\hline & Age & $\geq 40$ & -4.16 & -8.28 & 0.51 & & 0.121 \\
\hline & Gender & Male & -1.62 & -6.69 & 3.17 & 0.566 & 0.304 \\
\hline & Education & University & -3.97 & -8.75 & 0.94 & 0.155 & 0.922 \\
\hline & Ethnicity & White & -0.91 & -7.27 & 5.09 & 0.796 & 0.374 \\
\hline & Comorbidities & Present & 0.49 & -4.52 & 5.46 & 0.864 & 0.628 \\
\hline & Shocks & Yes & 2.59 & -4.23 & 9.59 & 0.511 & 0.212 \\
\hline \multirow{14}{*}{$\begin{array}{l}\text { Florida } \\
\text { Patient } \\
\text { Acceptance } \\
\text { Scale } \\
\text { (FPAS) }\end{array}$} & Time & 3 months & \multicolumn{2}{|l|}{ Reference } & & & $N A$ \\
\hline & & 6 months & 16.48 & 4.81 & 27.89 & 0.028 & \\
\hline & & 1 year & 21.97 & 8.13 & 35.34 & \multirow[t]{2}{*}{0.013} & \\
\hline & & & & & & & \\
\hline & & 2 years & -1.87 & -21.20 & 15.79 & 0.873 & \\
\hline & & 3 years & 2.74 & -19.84 & 24.21 & 0.845 & \\
\hline & & 4 years & 43.77 & 20.01 & 67.64 & 0.005 & \\
\hline & & 5 years & 6.36 & -17.80 & 29.31 & 0.672 & \\
\hline & Age & $\geq 40$ & -1.54 & -12.91 & 8.86 & 0.810 & 0.200 \\
\hline & Gender & Male & 9.23 & -2.37 & 20.99 & 0.178 & 0.323 \\
\hline & Education & University & 4.22 & -7.27 & 15.61 & 0.526 & 0.330 \\
\hline & Ethnicity & White & 5.21 & -8.93 & 19.93 & 0.532 & 0.066 \\
\hline & Comorbidities & Present & -2.59 & -14.22 & 9.17 & 0.702 & 0.094 \\
\hline & Shocks & Yes & -14.32 & -30.51 & 2.00 & 0.132 & 0.369 \\
\hline
\end{tabular}

Reference categories are: gender = female, education level = no university, ethnicity = white ethnicity, age category = young age, shocks $=$ no shocks, comorbidities $=$ no comorbidities present. Abbreviations: $H A D S=$ Hospital anxiety and depression scale.

aBased on Wald's t-test

${ }^{b}$ Based on type III ANOVA table with Satthertwaite's method

"Model including interaction between timepoint and shocks and ethnicity respectively is rank deficient. The interactions timepoint *shocks and timepoint ${ }^{*}$ ethnicity were therefore excluded from the model. 
medRxiv preprint doi: https://doi.org/10.1101/2021.04.26.21256086; this version posted May 24, 2021. The copyright holder for this preprint (which was not certified by peer review) is the author/funder, who has granted medRxiv a license to display the preprint in perpetuity. It is made available under a CC-BY-ND 4.0 International license

\section{FIGURE LEGENDS}

FIGURE 1: Predicted values of outcome measures with $95 \%$ confidence intervals over

follow-up based on mixed model analysis. The dotted line indicates the cut-off score and zscore for respectively HADS and SF-36 scores.

Abbreviations: HADS, Hospital Anxiety and Depression Scale (HADS); FSAS, Florida Shock Anxiety Scale; MC, Mental Component; PC, Physical Component. 


\section{FIGURE1}

HADS Anxiety

HADS Depression

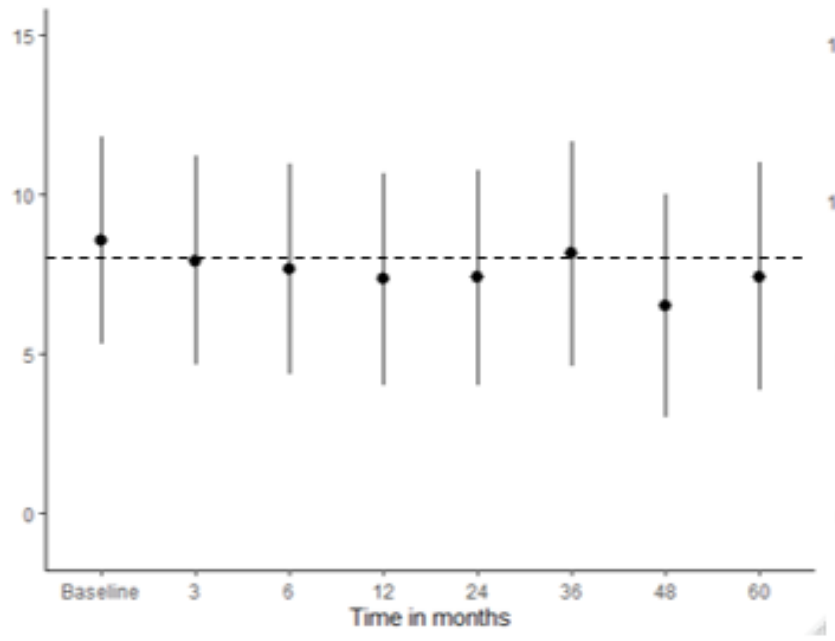

SF-36 MC score

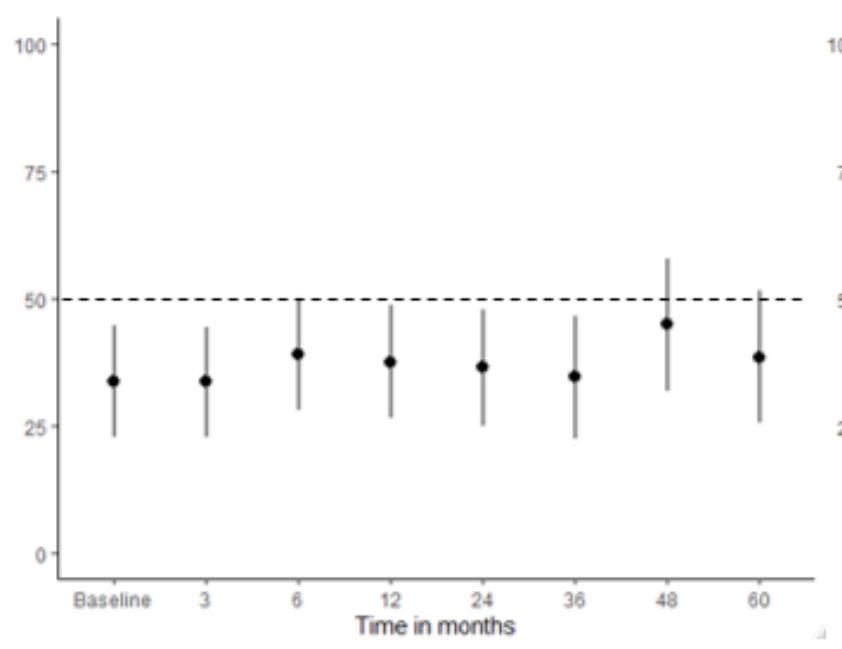

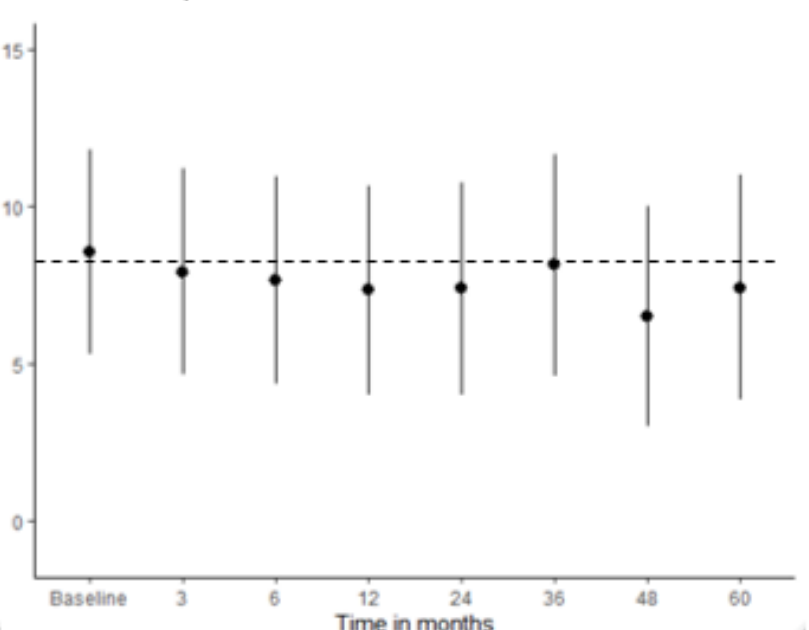

SF-36 PC score

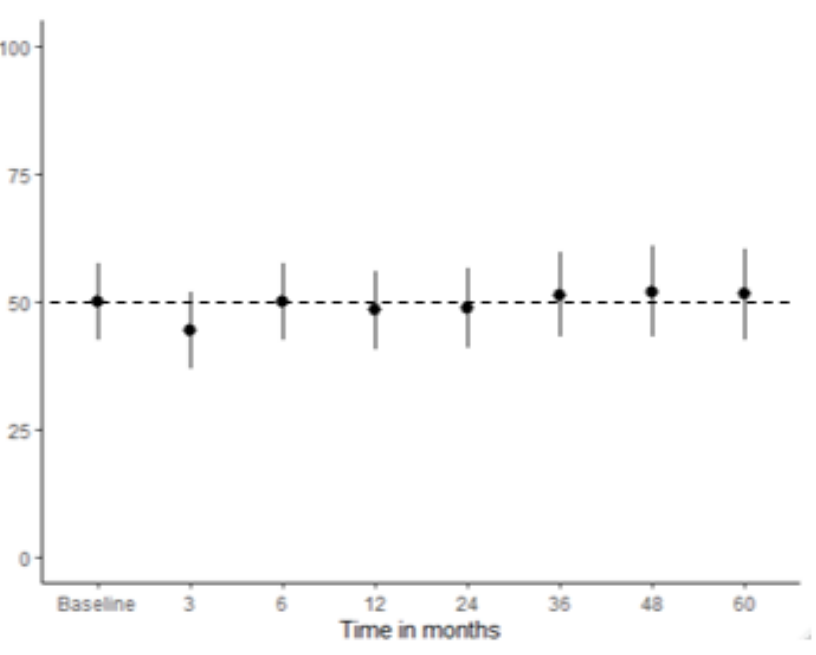

FSAS
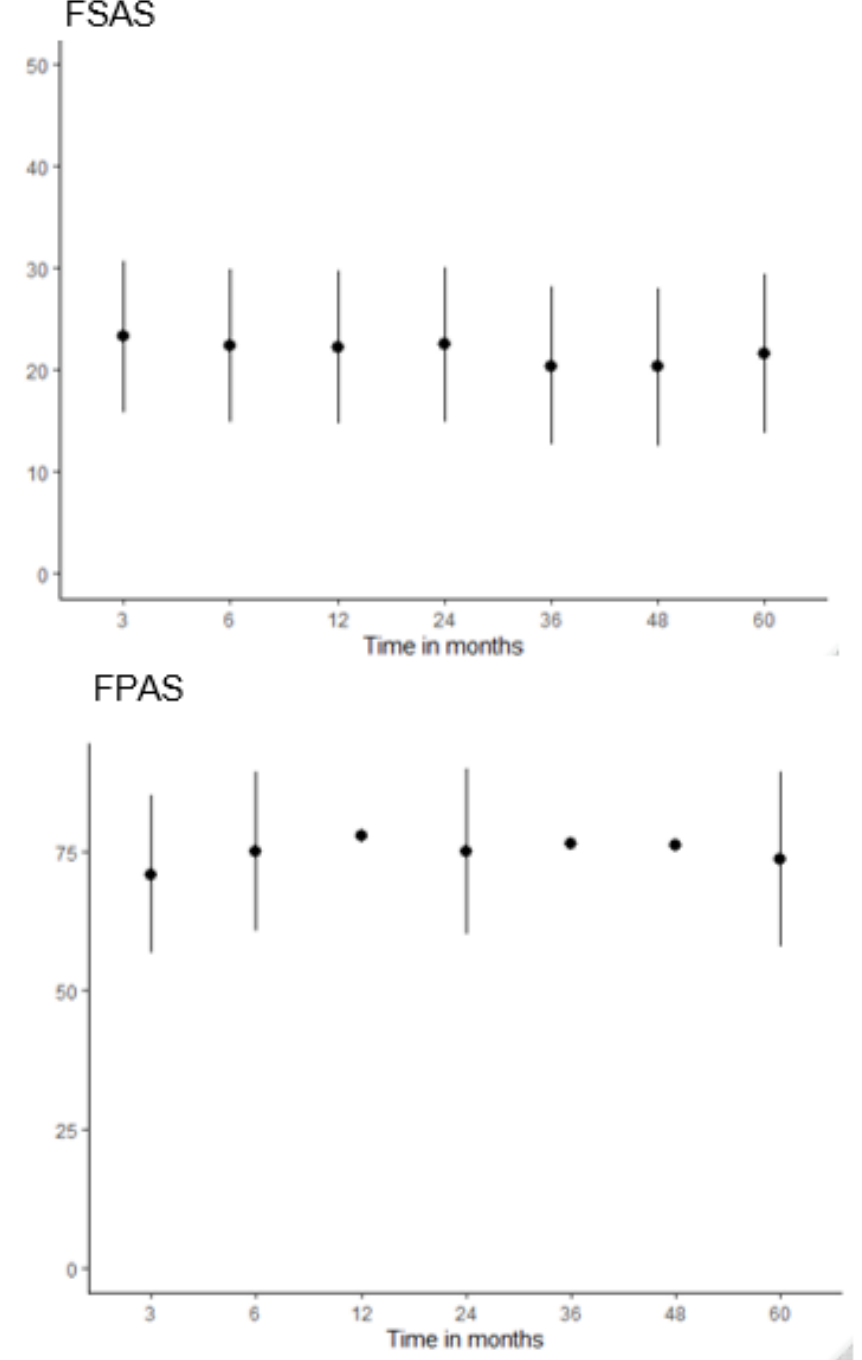